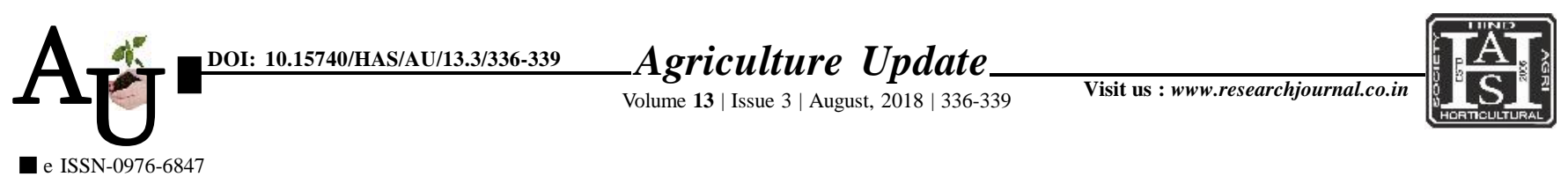

\title{
Research Article: Knowledge of soil test recommendations by the orange growers
}

\author{
A.R. Lothe, A.N. Deshmukh, S.N. Gawande and N.B. Lothe
}

Article Chronicle: Received :

21.05.2018;

Revised :

28.06.2018;

Accepted :

12.07.2018

KEY Words:

Knowledge, Soil testing techniques, Recommendations

Author for correspondence :

\section{A.N. Deshmukh}

Department of

Extension Education,

Shri Shivaji Agriculture

College, Amravati (M.S.) India

Email : abhaydeshmukh $40 @$ rediffmail.com

See end of the article for authors' affiliations
SUMMARY : The present study on knowledge of soil test recommendations by the orange growers was conducted in Amravati, Chandur Railway and Chandur Bazar talukas of Amravati district. The study was planned to investigate knowledge of soil testing techniques and its recommendations by the orange growers. The exploratory research design of social research was used for the present investigation. The present study was undertaken in Amravati district of Vidarbha in Maharashtra state. The farmers were selected from three taluka Amravati, Chandur Railway and Chandur Bazar, on the basis of having area under orange orchards and orange growers were selected randomly having productive orange orchards. Thus, the total fourteen villages were selected. Data were collected by personally interviewing the respondents with the help of pretested and structured interview schedule. The data collected were tabulated and the statistical tools namely mean, standard deviation, percentage, frequency, correlation co-efficient were employed for interpretation of the findings. Null hypothesis set for the study was tested for its acceptance or rejection. The respondents were selected by proportionate random sampling method to constitute sample size of 80 respondents. The salient findings of the present study revealed that the distributional analysis pertaining to age of respondents indicated that 56.25 per cent were in middle age group, education of respondents indicated that 22.5 per cent of the respondents were studied high school, and 43.75 per cent of the respondents had annual income between 1,00,001 to 1,50,000. From all selected respondents, majority (93.75\%) of the respondents were having upto 2 ha area under orange orchard, 62.5 per cent respondents were having orange orchard from 7 to 12 years age. 52.5 per cent respondents availed employment guarantee scheme for plantation of orange orchard. Most (48.75\%) of the respondents had deep type of soil. Majority (78.75\%) of the respondents had farming experience between 8 to 14 years. More than half $(100.00 \%)$ respondents have to travel distance upto $50 \mathrm{~km}$ from their village for soil testing laboratory. More than half of the respondents (73.75\%) had medium level of extension contact, 57.5 per cent of the respondents using drip as a method of irrigation. Out of the total selected orange growers $65.00 \%$ of respondents were having medium level of knowledge about soil testing techniques and its recommendations. The variables namely education, type of soil, extension contact and method of irrigation were positively and highly significantly correlated with knowledge of soil testing techniques at 0.01 level of probability. The variable namely age of orchards, annual income, employment guarantee scheme availed and farming experience were positively and significantly correlated with knowledge of soil testing techniques at 0.05 level of probability. Whereas, area under orange orchards, were non-significantly correlated with knowledge about soil testing techniques and its recommendation at 0.05 level of probability. Whereas, age of respondents, distance from soil testing laboratory were negatively and non-significantly correlated with knowledge of soil testing techniques and its recommendation as per the soil test report. 